\title{
AKTIVITAS ANTIBAKTERI EKSTRAK KARANG LUNAK SINULARIA SP. DENGAN METODE BROTH-DILUTION
}

\section{ANTI-BACTERIAL ACTIVITY OF THE SOFTCORAL SINULARIA SP USING BROTH-DILUTION METHOD}

\author{
Alismi M. Salanggon', Sari Aswani ${ }^{1}$, Asriani Hasanuddin², Roni Hermawan', \\ Putut Har Riyadi ${ }^{3}$, Didit Kustantio Dewanto ${ }^{1}$, \& Wendy Alexander Tanod ${ }^{1}$ \\ ${ }^{1}$ Sekolah Tinggi Perikanan dan Kelautan (STPL) Palu \\ Jalan Soekarno-Hatta KM 6 Kampus Madani, Mantikulore, Kota Palu, 94118 \\ ${ }^{2}$ Fakultas Peternakan dan Perikanan, Universitas Tadulako \\ Jalan Soekarno-Hatta KM 9, Tondo, Kota Palu, 94118 \\ ${ }^{3}$ Fakultas Perikanan dan Ilmu Kelautan, Univeristas Diponegoro \\ Jalan Prof. Soedarto, SH, Tembalang, Kota Semarang, 1269 \\ e-mail : wendytanod@stplpalu.ac.id
}

Diterima tanggal: 13 Juni 2020 ; diterima setelah perbaikan: 9 November 2020 ; Disetujui tanggal: 5 Desember 2020

\begin{abstract}
ABSTRAK
Karang lunak merupakan bagian dari ekosistem terumbu karang, yang mengandung senyawa bioaktif dan dapat berperan sebagai alat pertahanan diri serta memiliki kemampuan sebagai senyawa antibakteri. Penelitian ini bertujuan untuk menginvestigasi potensi ekstrak karang lunak Sinularia sp. sebagai antibakteri dengan metode broth-dilution. Karang Lunak Sinularia sp. dikoleksi dari perairan Desa Kabonga Besar, Sulawesi Tengah, dan dimaserasi dengan diklorometana : methanol. Ekstrak Sinularia sp. dilakukan pengujian skrining metabolit kimia dan pengujian antibakteri dengan metode broth-diluttion. Hasil skrining ekstrak Sinularia sp. terdeteksi senyawa metabolit flavonoid, saponin, alkaloid dan steroid. Ekstrak Sinularia sp. memberikan pengaruh terhadap total koloni Escherichia coli dan Pseudomonas aeruginosa. Ekstrak Sinularia sp. dapat menghambat pertumbuhan E. coli dengan konsentrasi minimum $1,76 \pm 0,10 \mathrm{mg} / \mathrm{mL}$, sedangkan pada $P$. aeruginosa konsentrasi minimum yang dibutuhkan $1,85 \pm 0,14 \mathrm{mg} / \mathrm{mL}$. Konsentrasi bunuh minimum ekstrak Sinularia sp. yang dibutuhkan dalam membunuh $E$. coli, yaitu 7,06 $\pm 0,42 \mathrm{mg} / \mathrm{mL}$, sedangkan pada $P$. aeruginosa, yaitu 7,38 $\pm 0,54 \mathrm{mg} / \mathrm{mL}$. Penelitian ini disimpulkan bahwa senyawa bioaktif dari metabolit ekstrak karang lunak Sinularia sp. berpotensi sebagai senyawa antibakterial terhadap $E$. coli dan $P$. aeruginosa. Oleh karena itu, perlu diinvestigasi lebih lanjut dari identifikasi profil bioaktif karang lunak Sinularia $s p$.
\end{abstract}

Kata Kunci: Anti bakteri, karang lunak, sinularia. sp, Broth-dilution, Metabolit, Steroid.

\section{ABSTRACT}

Soft coral is part of the coral reef ecosystem, contains bioactive, and can an antibacterial. This study aimed to explore the potential of soft coral Sinularia sp. as an antibacterial by the broth-dilution method. Sinularia sp. collected from Kabonga Besar, Central Sulawesi. Extracts of Sinularia sp. carried out chemical metabolite and antibacterial. Screening metabolites of Sinularia sp. extracts contain flavonoids, saponins, alkaloids, and steroids. Sinularia sp. extracts gave effect to the total colonies of E. coli and P. aeruginosa. Sinularia sp. could inhibit E. coli growth with a minimum inhibitory concentration of $1.76 \pm 0.10 \mathrm{mg} / \mathrm{mL}$, where P. aeruginosa was $1.85 \pm 0.14 \mathrm{mg} / \mathrm{mL}$. This study concluded that bioactive compounds from soft coral extracts of Sinularia sp. potential as an antibacterial compound against E. coli and P. aeruginosa. Therefore, it is necessary to investigate further the identification of Sinularis sp. extracts bioactive profile.

Keywords: Anti-bacterial, softcoral, sinularia.sp, brith-dilution, Metabolite, steroid. 


\section{PENDAHULUAN}

Terumbu karang merupakan salah satu ekosistem unik yang menyediakan biota dengan fungsi ekologis, ekonomis, wisata, kimia dan biologis (Salanggon \& Finarti, 2016). Salah satu biota penghuni terumbu karang, yaitu karang lunak. Karang lunak (filum Cnidaria) merupakan kelompok hewan invertebtara yang melimpah dan sangat beragam pada ekosistem terumbu karang (Tanod et al., 2015). Menurut Colin \& Arneson (1995), terminologi karang lunak (soft coral) biasanya merujuk pada subkelas alyconaria (octocoralia). Subkelas alcyonaria memiliki karakteristik morfologi, warna, dan ukuran yang bervariasi (Putra et al., 2016a).

Bentuk karang lunak mempunyai tubuh yang lunak dan lentur serta mempunyai tangkai yang melekat pada substrat yang keras terutama pada karang mati. Walaupun bahan penyusun karang lunak dan karang keras sama yaitu kapur, tubuh karang lunak ini lebih lunak dan kenyal. Hal ini disebabkan karena karang lunak tidak memiliki kerangka kapur yang keras seperti halnya karang batu (Wanda et al., 2018). Jaringan tubuh karang lunak didukung oleh sekumpulan duriduri kecil yang kuat dan tersusun sedemikian rupa sehingga tubuhnya yang lunak dan lentur tidak mudah putus dan sobek. Duri-duri ini disebut spikula dan mengandung kalsium karbonat. Karang lunak juga merupakan hewan yang bersifat allelopatik yaitu hewan yang mengeluarkan zat tertentu dari tubuhnya sehingga hewan lain ataupun predator tidak akan mendekatinya (Chen et al., 2012).

Sinularia merupakan salah satu genus karang lunak dengan jumlah terbanyak di perairan (Dewanto et al., 2019). Karang lunak Sinularia $s p$. tumbuh dan berkembang optimal pada perairan bersuhu rata-rata tahunan $23-25^{\circ} \mathrm{C}$, namun juga dapat mentoleransi suhu sampai $36-40^{\circ} \mathrm{C}$ dan salinitas sebesar 32-35\% . Habitat karang lunak umumnya dijumpai berada pada ekosistem terumbu karang (Tanod et al., 2018).

Karang lunak memproduksi suatu substansi sebagai alat pertahanan diri yang dikenal dengan senyawa bioaktif (Tanod et al., 2019a). Senyawa bioaktif ini berupa terpenoid, steroid dan steroid glikosida yang dapat berperan sebagai antibakteri patogen (Wang et al., 2012). Studi literatur menunjukkan Sinularia sp. memproduksi senyawa bioaktif dengan sifat antibakteri (Sun et al., 2012; Liang et al., 2013; Rozirwan et al., 2014; Rajaram et al., 2014; Putra et al., 2016b; and Tanod, 2019b). Selain itu, Sinularia sp. juga dilaporkan memiliki aktivitas antiviral, anti-inflamasi (Cheng et al., 2010); inhibitor NFkB dan iNOS (Riyadi et al., 2019) dan inhibitor NO (Fattorusso et al., 2011 dan Putra et al., 2012).

Ekplorasi pencarian substansi bioaktif yang memiliki aktivitas biologis dari perairan Indonesia, khususnya perairan sulawesi sudah banyak dilakukan. Akan tetapi ekplorasi substansi bioaktif dari karang lunak asal Sulawesi Tengah belum banyak dilakukan. Chasanah (2008) mengatakan bahwa perairan Sulawesi termasuk zona transisi berdasarkan pengelompokkan wallace, yang diketahui memiliki potensi biodiversitas organisme yang tinggi. Potensi biodiversitas yang tinggi, akan diikuti oleh potensi biodiversitas substansi bioaktif dan aktivitas biologis yang tinggi.

Karang lunak dilaporkan memproduksi $60 \%$ substansi bioaktif yang berpotensi sebagai senyawa obat (Higa et al., 2001 dan Sheu et al., 2002). Studi literatur menyatakan bahwa karang lunak genus Sinularia sumber dari turunan senyawa terpenoid dan steroid. Terpenoid dan steroid merupakan salah satu golongan senyawa yang paling banyak ditemukan pada karang lunak (Wang et al., 2012 dan Tseng et al., 2013). Secara alamiah, senyawa terpenoid dan steroid digunakan oleh karang lunak sebagai penangkal terhadap serangan predator, dalam hal memperebutkan ruang lingkup dan dalam proses reproduksi (Manuputty, 2002 dan Lu et al., 2008).

Penelitian yang mengeksplorasi aktivitas antibakteri umumnya menggunakan metode difusi dengan mengukur diameter zona bening (Hermawan et al., 2007). Metode difusi hanya mengukur zona hambat yang terbentuk tetapi, jumlah bakteri yang dibunuh ataupun dihambat tidak dapat dihitung secara pasti. Salah satu metode pengujian antibakteri, yaitu metode broth-dilution. Metode ini dapat menghitung kuantitas jumlah bakteri yang dihambat maupun dibunuh dengan jelas (Wiegand et al., 2008). Metode broth-dilution menguji kemampuan suatu substansi bioaktif (agen antibakteri) dalam kemampuannya menghambat pertumbuhan atau membunuh bakteri uji pada media broth (European Committee for Antimicrobial Susceptibility Testing [EUCAST], 2003).

Substansi antibakteri merupakan substansi yang dapat menghambat pertumbuhan atau membunuh bakteri. Beberapa hasil penelitian melaporkan bahwa beberapa bakteri sudah menunjukkan resistensi terhadap substansi antibakteri yang ada saat ini (Radic \& Strukelj, 2012). Berdasarkan uraian diatas, maka tujuan 
penelitian ini, yaitu menginvestigasi potensi ekstrak karang lunak Sinularia sp. sebagai antibakteri dengan metode broth-dilution. Bakteri yang digunakan dalam penelitian, yaitu bakteri gram negatif Escherichia coli dan Pseudomonas aeruginosa.

\section{BAHAN DAN METODE}

Laboratorium Teknologi Hasil Perikanan, Sekolah Tinggi Perikanan dan Kelautan (STPL) Palu dan di Laboratorium Teknologi Hasil Ternak Universitas Tadulako, yang dilakukan pada bulan April - Juli 2019.

\section{Alat dan Bahan}

Alat yang digunakan adalah laminar air flow, autoklaf, timbangan analitik, cawan petri, test tube, inkubator, gelas Erlenmeyer, jarum ose, pipet, pinset, pembakar bunsen, pipet mikro, masker, sarung tangan, pipet vakum, pipet tetes, rotary vakum evavorator (EYELA N-100), McFarland Standard 4 (Hi-Media). Bahan yang digunakan adalah karang lunak Sinularia sp., natrium broth (NB) (Meck), diklorometana (Merck), metanol (Merck), Plate Count Agar (PCA) (Merck), aquades, tisu, alkohol $70 \%$, kapas, kertas saring whatman, alumunium foil, plastik wrap, plastik sampel, isolat bakteri Escherichia coli ATCC 25922 dan Pseudomonas aeruginosa ATCC 27853.

\section{Identifikasi dan Ekstraksi Karang Lunak}

Karang Lunak Sinularia sp. dikoleksi pada April 2019 dari perairan Desa Kabonga Besar Kabupaten Donggala, Sulawesi Tengah. Koordinat pengambilan sampel, yaitu pada 042'22.3' LS dan 11946'13.0' BT (Gambar 1). Karang lunak diidentifikasi berdasarkan pedoman Fabricus \& Alderslade (2001). Sampel karang lunak diamati bentuk koloni dan bentuk sklerit. Pedoman identifikasi karang lunak disedikan dari Australian Institute of Marine Science.

Karang lunak dipotong menjadi ukuran yang lebih kecil dan dimasukkan ke dalam botol plastik. Setelah itu sampel karang lunak ditimbang seberat $500 \mathrm{~g}$ untuk dimaserasi dengan diklorometana : methanol (1:1 v/v) selama 48 jam dengan perbandingan 1:3 b/v. Setelah itu, rendaman sampel disaring. Filtrat yang diperoleh dievaporasi pelarut organiknya untuk mendapatkan ekstrak karang lunak. Ekstrak ditimbang beratnya dan disimpan dalam lemari pendingin.

\section{Uji Metabolit Kimia}

Skrining kandungan metabolit kimia (alkaloid, flavonoid, steroid, triterpenoid, saponin dan polifenol) dalam ekstrak karang lunak dilakukan dengan metode
Harborne (1998).

\section{Pengujian Antibakteri dengan Metode Broth- dilution}

Metode broth-dilution berdasarkan pedoman EUCAST (2003) dan Wiegand et al. (2008) yang dimodifikasi. Pengujian dilakukan dengan membuat seri pengenceran antibakteri dengan menggunakan medium nutrien broth yang ditambahkan dengan bakteri uji. Suspensi bakteri Escherichia coli dan Pseudomonas aeruginosa disiapkan dalam larutan fisiologis $\mathrm{NaCl}(0.9 \% \mathrm{~b} / \mathrm{v})$ dan dan diatur kepadatannya sama dengan standar Mc Farland $4\left(1,2 \times 10^{9} \mathrm{Koloni} / \mathrm{mL}\right)$. Kemudian sebanyak 1 $\mathrm{mL}$ suspensi bakteri uji ditambahkan ke media natrium broth $9 \mathrm{~mL}$. Kemudian, sebagai perlakuan pada tiap tabung diberi $100 \mu \mathrm{L}$ ekstrak karang lunak dengan konsentrasi sebagai berikut :

Perlakuan 1 :Tanpa pemberian ekstrak

Perlakuan 2 : Konsentrasi ekstrak $125 \mathrm{mg} / \mathrm{mL}$

Perlakuan 3 : Konsentrasi ekstrak $250 \mathrm{mg} / \mathrm{mL}$

Perlakuan 4 : Konsentrasi ekstrak $500 \mathrm{mg} / \mathrm{mL}$

Perlakuan 5 : Konsentrasi ekstrak $750 \mathrm{mg} / \mathrm{mL}$

Perlakuan 6 : Konsentrasi ekstrak $1000 \mathrm{mg} / \mathrm{mL}$

Bakteri uji diinkubasi selama 24 jam pada suhu $37^{\circ} \mathrm{C}$. Lalu, dilakukan penghitungan total koloni berdasarkan prosedur pengujian angka lempeng total mengikuti Standar Nasional Indonesia (SNI) No. 01-2332.3 Tahun 2006 tentang penentuan angka lempeng total (Badan Standarisasi Nasional [BSN], 2006). Pengujian ini dilakukan dengan 3 kali pengulangan.

Sebanyak $1 \mathrm{~mL}$ dari tiap perlakuan dipindahkan ke dalam tabung media NB $9 \mathrm{~mL}$, sehingga diperoleh pengenceran 10-2. Seri pengenceran ini dilakukan sampai dengan pengenceran 10-4. Setelah itu, diambil $1 \mathrm{~mL}$ dari seri pengenceran 10-2, 10-3, 10-4 dan dimasukkan ke dalam cawan petri yang berisi media PCA. Langkah ini dilakukan secara duplo untuk tiap seri pengenceran. Media PCA yang sudah ditambahkan larutan sampel, dilakukan pemutaran ke depan dan belakang (membentuk angka 8) agar larutan sampel dapat tersebar merata diatas media PCA. Media PCA ini diinkubasi selama 48 jam pada suhu $35^{\circ} \mathrm{C}$ dengan posisi cawan terbalik. Lalu dihitung total koloni bakteri uji yang tumbuh. Penghitungan total koloni dilakukan menggunakan metode Harrigan dengan persamaan (1).

$$
N=\frac{\Sigma C}{\left[\left(1 \times n_{1}\right)+\left(0,1 \times n_{2}\right) \times d\right.}
$$




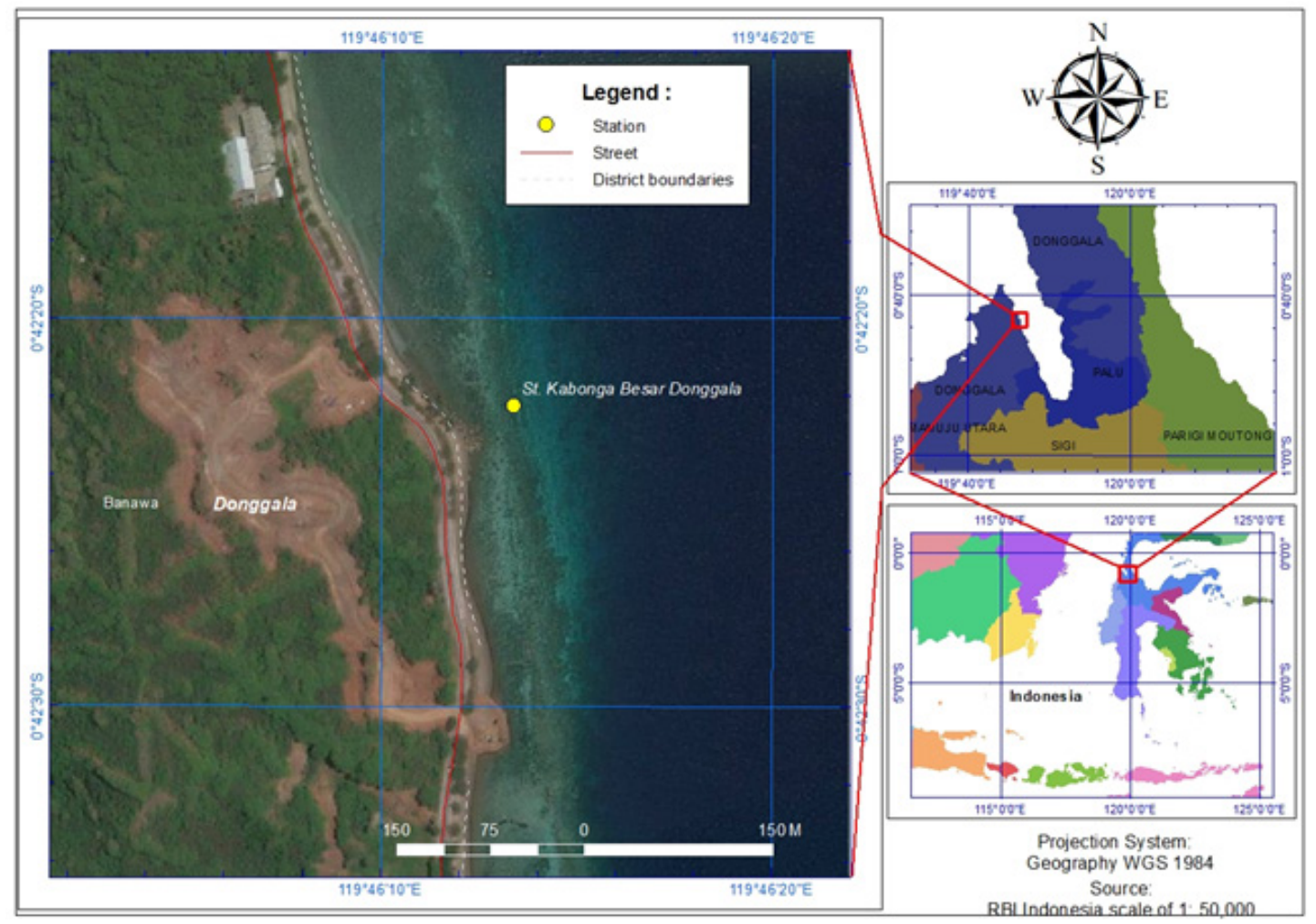

Gambar 1. Peta Lokasi Sampling Karang Lunak Sinularia sp di Teluk Palu.

Figure 1. The sampling stations of Sinularia sp in Palu Coastal Bay.

dimana,

$N \quad$ : Jumlah koloni, dinyatakan dalam koloni/mL atau $\mathrm{koloni} / \mathrm{g}$

$\Sigma C \quad$ : Jumlah koloni pada semua cawan yang dihitung

$n_{1} \quad$ : Jumlah cawan pada pengenceran pertama yang dihitung

$n_{2} \quad$ : Jumlah cawan pada pengenceran kedua yang dihitung

$d \quad$ : Pengenceran pertama yang dihitung.

Penentuan Konsentrasi Hambat Minumum (KHM) dan Konsentrasi Bunuh Minimum (KBM)

Penentuan nilai KHM dan KBM mengikuti metode Bloomfield (1991), yaitu dilakukan dengan membuat grafik regresi linier pada sumbuh $X$ (In $M o=$ In $M t)$ dan sumbu $Y(Z 2)$. Nilai Mt merupahkan titik potong grafik regresi linier pada sumbuh $X$. Nilai KHM adalah $0,25 \mathrm{Mt}$ dan nilai $K B M=4 \times K H M$.

\section{HASIL DAN PEMBAHASAN}

\section{Identifikasi dan Skrining Metabolit Ekstrak} Karang Lunak Sinularia sp.

Berdasarkan bentuk koloni dan skleritnya, karang lunak yang digunakan pada penelitian ini teridentifikasi sebagai Sinularia sp. seperti Gambar 2. Setelah diekstraksi, sampel dilakukan pengujian metabolit kimia, untuk mengetahui kandungan metabolit dalam ekstrak karang lunak Sinularia sp.(Tabel 1).

Tabel 1 menunjukkan kehadiran senyawa metabolit flavonoid, saponin, alkaloid dan steroid dalam ekstrak karang lunak. Dalam penelitian sebelumnya juga telah mendeteksi kehadiran metabolit saponin, steroid dan alkaloid dalam ekstrak karang lunak (Tanod et al., 2019c). Rachmaniar (1995) menyatakan bahwa saponin merupakan metabolit dengan karakteristik rasa pahit dan bersifat toksik bagi amfibi dan ikan, serta memiliki fungsi farmakologis. Bagi karang lunak metabolit saponin berfungsi dalam mencegah serangan predator, digunakan sebagai senjata kimia dalam, dan berperan dalam proses reproduksi (Liang \& Guo, 2013).

Jia et al. (2005) melaporkan karang lunak memproduksi metabolit steroid yang memiliki aktivitas anti-inflamasi, antikanker, antibakteri dan anti-alergi. Karang lunak memproduksi metabolit steroid sebagai perlindungan dari predator (Handayani et al., 1997). Putra et al., (2016b) melaporkan adanya metabolit steroid dan saponin dari karang lunak Sinularia sp. Hasil penelitian lain juga melaporkan produksi senyawa steroid dari karang lunak Sinularia depressa (Liang et al., 2013), Sinularia polydactyla (Shaaban et al., 2013), 


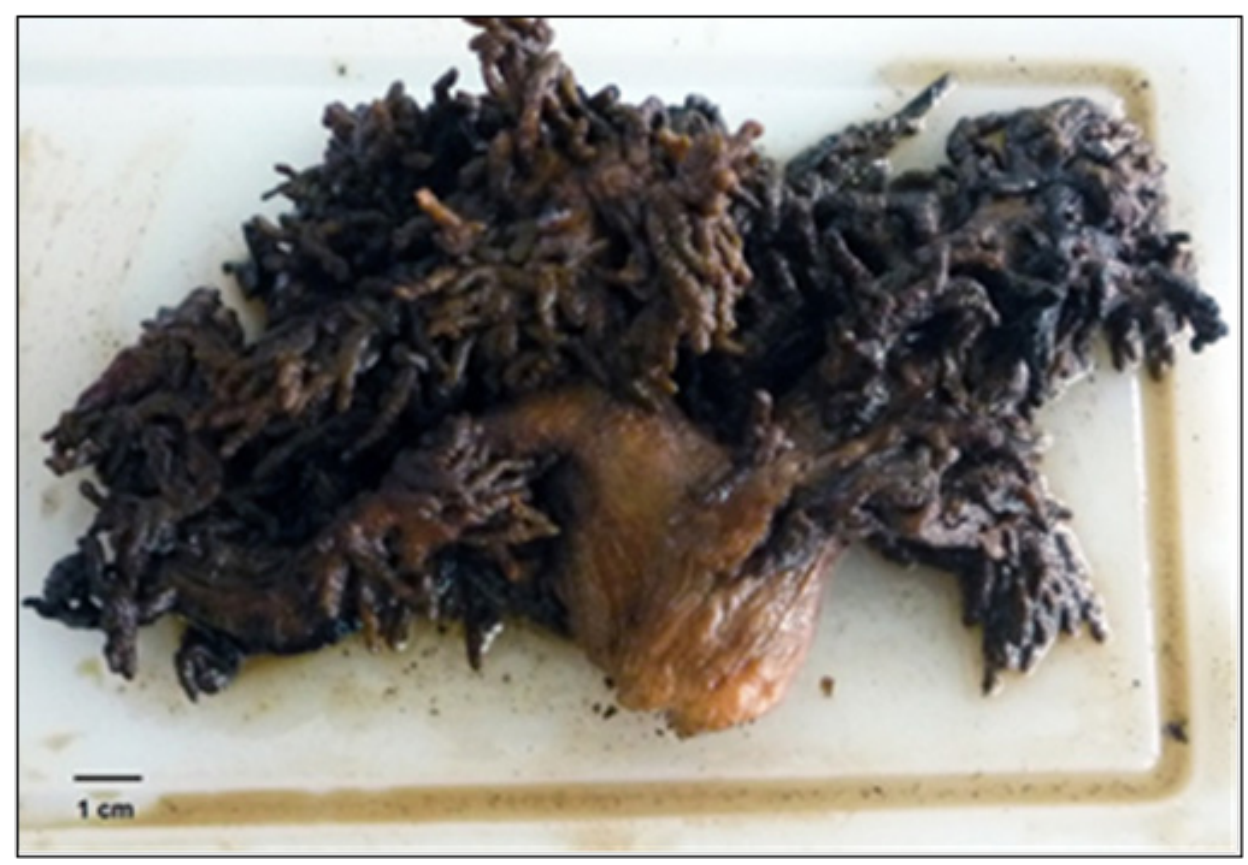

Gambar 2. Karang Lunak Sinularia sp hasil sampling.

Figure 2. Sinularia sp. Soft Coral sampling result.

dan Sinularia kavarattiensis (Rajaram et al., 2014). Metabolit steroid umumnya memiliki aktivitas sebagai antibakteri (Alhaddad et al., 2019). Mekanisme kerja antibakteri dari metabolit steroid diduga dengan merusak membran sel bakteri (Cowan, 1999). Vickery \& Vickery (1981) menyatakan metabolit steroid berkerja dengan meningkatkan permeabilitas membran sel bakteri, sehingga menyebabkan kebocoran sel bakteri.

Tabel 1 juga menunjukkan metabolit alkaloid juga terdeteksi dari ekstrak karang lunak Sinularia $s p$. Fattorusso et al. (2008) melaporkan produksi alkaloid dari karang lunak. Karang lunak memproduksi lendir yang mengandung metabolit alkaloid dan berperan dalam persaingan memperebutkan ruang dan pertahanan diri. Metabolit flavonoid merupakan metabolit yang tidak umum ditemukan dari ekstrak karang lunak, diduga metabolit yang terdeteksi merupakan turunan dari senyawa fenolik. Dari penelitian sebelumnya terdeteksi golongan fenolik dari ekstrak karang lunak (Dewanto et al., 2019). Metabolit flavonoid memiliki struktur fenolik dan mempunyai satu gugus karbonil kompleks dengan sifat protein terlarut yang dapat melarutkan ekstraseluler dinding sel bakteri (Ravikumar et al., 2010). Naidu (2002) menyatakan flavonoid merupakan metabolit dengan spektrum antimikroba yang luas dengan menurunkan sistem kekebalan pada organisme target. Selain dapat melarutkan protein dari dinding sel bakteri, metabolit flavonoid juga dapat bekerja dengan mendenaturasi protein dalam sel. Gugus $\mathrm{OH}$ pada flavonoid dapat berikatan dengan protein internal dari membran sel bakteri, sehingga menyebabkan gangguan transpor aktif

Tabel 1. Hasil uji metabolit kimia esktrak Sinularia sp

Table 1. Chemical metabolite assays of Sinularia sp. extracts

\begin{tabular}{lllllll}
\hline Sampel & Flavonoid & Saponin & $\begin{array}{l}\text { Polifenol } \\
\text { (Tanin) }\end{array}$ & AlkoloidSteroid & Triterpenoid \\
\hline Sinularia sp. & + & + & - & + & + & - \\
Standar & Terbentuk & Busa stabil & Terbentuk & Terbentuk & Terbentuk & $\begin{array}{l}\text { Terbentuk } \\
\text { endapan }\end{array}$ \\
& warna oranye, & terbentuk & endapan & warna hijau & warna coklat \\
& pink atau merah & selama 15 & berwarna & oranye & atau biru & atau coklat \\
& & menit & coklat & & & kemerahan \\
\hline
\end{tabular}

Keterangan : (+) Ada; (-) Tidak Ada 
$\mathrm{NA}^{+}$dan $\mathrm{K}^{+}$. Dengan adanya gangguan transpor aktif, menyebabkan transpor ion $\mathrm{NA}^{+}$dan $\mathrm{K}^{+}$menjadi tidak terkontrol dalam sel bakteri. Hal ini dapat membuat membran sel bakteri menjadi pecah, sehingga bakteri mengalami lisis (Scheuer, 1994).

\section{Aktivitas Antibakteri Ekstrak Karang Lunak Sinularia sp.}

Evaluasi aktivitas antibakteri dari ekstrak karang lunak Sinularia $s p$. dilakukan dengan menghitung jumlah total koloni bakteri E. coli dan P. aeruginosa yang tumbuh pada media nutrien broth. Hasil pengujian menunjukkan total koloni $E$. coli pada perlakuan tanpa pemberian ekstrak, yaitu $1,43 \times 10^{7} \pm 2,52 \times 10^{6}$ Koloni/ $\mathrm{mL}$. Ekstrak Sinularia sp. memberikan pengaruh terhadap jumlah total koloni E. coli yang tumbuh seperti terlihat pada Gambar 3a. Semakin tinggi konsentrasi ekstrak Sinularia sp., dapat menurunkan total koloni E. coli yang tumbuh.

Gambar 3b menunjukkan pemberian ekstrak
Sinularia $s p$. juga juga mempengaruhi total koloni $P$. aeruginosa. Hasil pengujian menunjukkan total koloni $P$. aeruginosa pada perlakuan tanpa pemberian ekstrak, yaitu $1,40 \times 10^{7} \pm 3,26 \times 10^{6} \mathrm{Koloni} / \mathrm{mL}$. Hasil pengujian juga menunjukkan semakin tinggi konsentrasi ekstrak Sinularia sp., juga dapat menurunkan total koloni $P$. aeruginosa.

Konsentrasi hambat minimum dan konsentrasi bunuh minimum ditentukan dengan regresi linier berdasarkan metode Bloomfield (1991). Konsentrasi hambat minimum merupakan konsentrasi minimum yang diperlukan suatu agen antibakteri untuk menghambat pertumbuhan bakteri, sedangkan konsentrasi bunuh minimum merupakan konsentrasi minimum yang diperlukan suatu agen antibakteri untuk membunuh bakteri tersebut(Tanod etal., 2018). Dari hasil pengujian aktivitas antibakteri dibuat suatu persamaan garis linier antara konsentrasi ekstrak Sinularia $s p$. terhadap total koloni E. coli dan P. aeruginosa Persamaan garis lurus ini bertujuan untuk mengevaluasi konsentrasi hambat

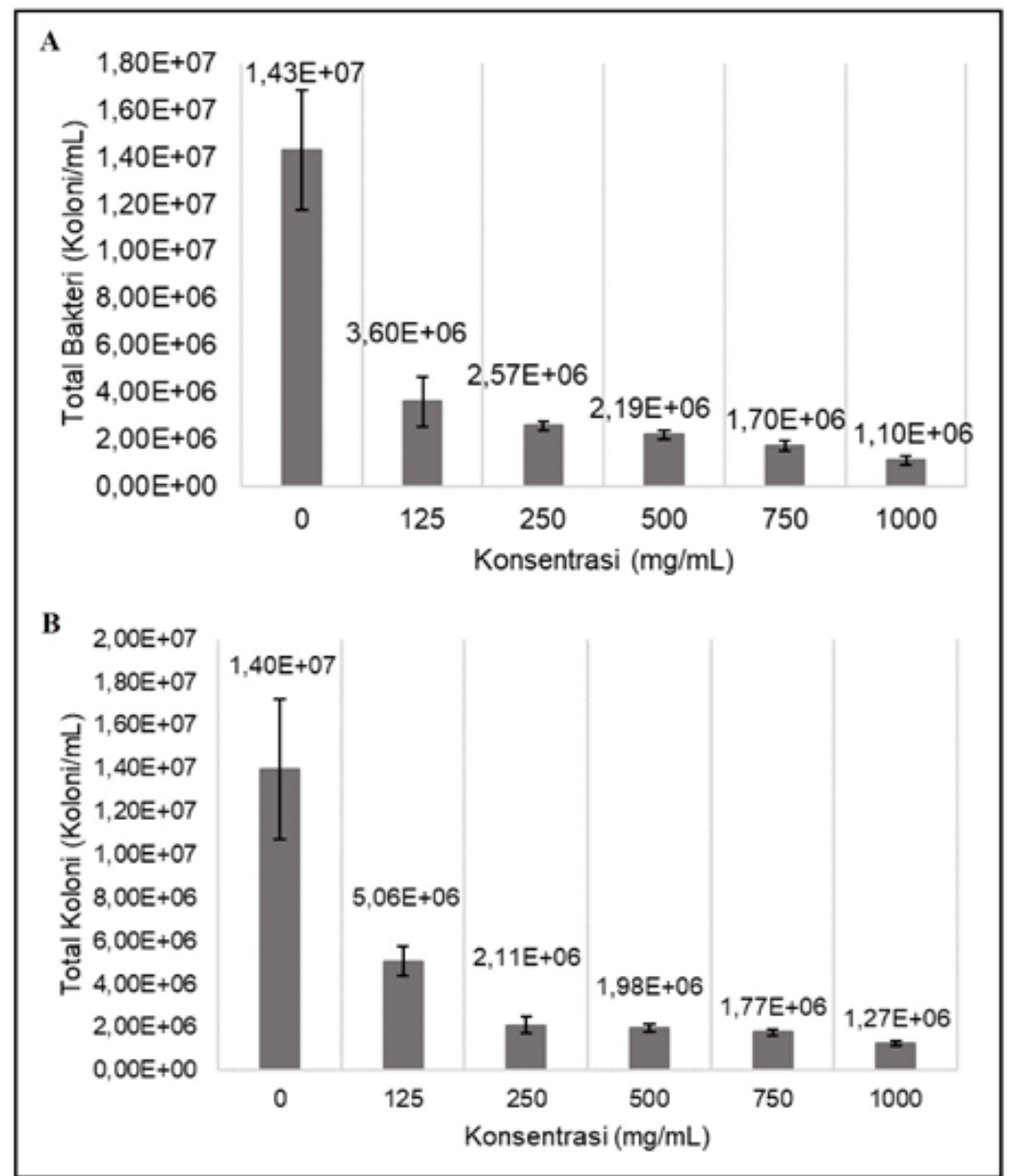

Gambar 3. Total koloni bakteri uji dengan pemberian ekstrak Sinularia sp,

(A.) Escherichia coli ATCC 25922 dan (B). Pseudomonas aeruginosa ATCC 27853.

Figure 3. Total bacteria colony test to the extract of Sinularia sp. sample,

(A.) Escherichia coli ATCC 25922 dan (B). Pseudomonas aeruginosa ATCC 27853. 
minimum (KHM) dan konsentrasi bunuh minimun (KBM) menurut metode Bloofield. Hasil evaluasi KHM dan KBM disajikan pada Tabel 2.

Tabel 2 menunjukkan nilai koefisien determinasi (R2) mendekati 1. Hal ini mengindikasikan bahwa semakin tinggi konsentrasi ekstrak Sinularia sp., maka jumlah koloni $E$. coli yang mengalami hambatan pertumbuhan sebesar $80-90 \%$. Sedangkan pada bakteri uji $P$. aeruginosa, ekstrak Sinularia sp. dapat menghambat pertumbuhan $P$. aeruginosa sebesar 60-70\%.

Penghambatan pertumbuhan atau kematian dari E. coli dan $P$. aeruginosa dipengaruhi oleh adanya substansi bioaktif yang terekstrak dari Sinularia $s p$. dan memiliki sifat antibakteri. Menurut Khatab et al. (2008) substansi bioaktif merupakan senyawa kimia aktif yang dihasilkan oleh organisme melalui jalur biosintetik metabolit sekunder. Metabolit sekunder yang dihasilkan oleh karang lunak memiliki keanekaragaman yang tinggi dan struktur kimia yang unik (Minh et al., 2011 dan Blunt et al., 2013). Hal ini dapat dipengaruhi oleh tingginya biodiversitas karang lunak dan pengaruh dari fisika kimia habitatnya, yaitu suhu, salinitas, arus, intensitas cahaya, dan tekanan (Murniasih, 2005). Metabolit sekunder diproduksi oleh organisme pada saat kebutuhan metabolisme primer sudah terpenuhi dan digunakan dalam mekanisme evolusi atau strategi adaptasi lingkungan (Yang et al., 2018). Kompetisi ruang dan makanan yang tinggi juga mempengaruhi organisme laut memproduksi metabolit sekunder (Ianora et al., 2006 dan Putz \& Proksch 2009).

Hasil penelitian ini didukung oleh hasil penelitian sebelumnya, yaitu empat senyawa dari Sinularia kavarattiensis menunjukkan kemampuan penghambatan yang moderat dari pertumbuhan Bacillus subtilis, Staphylococcus. aureus, Staphylococcus epidermidis, E. coli, P. aeruginosa dan Klebsiella pneumoniae (Rajaram et al., 2014). Dobretsov et al. (2015) melaporkan Sinularia sp. dari Bandar AlKhayran, Oman menunjukkan penghambatan terhadap pertumbuhan B. subtilis, E. coli, Micrococcus luteus, $S$. aureus, dan Salmonella $s p$. Ekstrak Sinularia $s p$. asal Lampung, Indonesia juga menunjukkan kemampuan aktivitas antibakteri terhadap B. subtilis, S. aureus, E. coli, and Vibrio eltor (Putra et al., 2016b).

Karang lunak memiliki fungsi ekologis sebagai salah satu organisme penghuni ekosistem terumbu karang. Karang lunak hidup pada perairan laut dengan variasi faktor lingkungan dan tingkat predasi yang tinggi, sehingga mampu memproduksi substansi dengan fungsi farmakologis dan nutraseutikal yang penting. Penelitian ini mengungkap potensi metabolit bioaktif dari ekstrak karang lunak Sinularia $s p$. dengan fungsi biologis sebagai kandidat antibakterial terhadap pertumbuhan E. coli dan P. aeruginosa.

\section{KESIMPULAN DAN SARAN}

Dari hasil penelitian dapat disimpulkan bahwa ekstrak karang lunak Sinularia sp. memproduksi senyawa aktif turunan dari golongan alkaloid, flavonoid, saponin, dan steroid. Senyawa aktif dari ekstrak Sinularia $s p$. mampu menghambat pertumbuhan bahkan membunuh koloni Escherichia coli dan Pseudomonas aeruginosa dengan metode uji broth-dilution. Oleh karena itu, perlu diinvestigasi lebih lanjut dari identifikasi profil senyawa aktif karang lunak Sinularia sp.

\section{UCAPAN TERIMA KASIH}

Terima kasih kepada Ketua Sekolah Tinggi Perikanan dan Kelautan (STPL) Palu dan Kepala Laboratorium

Tabel 2. Evalusasi konsentrasi hambat minimum dan konsentrasi bunuh minimun dari Ekstrak Sinularia sp. dengan metode Bloofield

Table 2. Evaluation of the minimum inhibitory concentration and minimum bactericidal concentration of the Sinularia sp. extracts with Bloomfield Method

\begin{tabular}{lllll}
\hline Bakteri Uji & Persamaan $(\mathbf{y}=\mathbf{b x}+\mathbf{a})$ & $\mathbf{R}^{2}$ & $\mathbf{K H M}(\mathbf{m g} / \mathbf{m L})$ & $\mathbf{K B M}(\mathbf{m g} / \mathbf{m L})$ \\
\hline Escherichia coli & $\mathrm{y}=-3 \times 10^{12} \mathrm{x}+2 \times 10^{13}$ & 0,93 & $1,76 \pm 0,10$ & $7,06 \pm 0,42$ \\
& $\mathrm{y}=-4 \times 10^{12} \mathrm{x}+3 \times 10^{13}$ & 0,92 & & \\
& $\mathrm{y}=-1 \times 10^{13} \mathrm{x}+7 \times 10^{13}$ & 0,83 & & \\
& & & & \\
Pseudomonas & $\mathrm{y}=-7 \times 10^{12} \mathrm{x}+5 \times 1013$ & 0,77 & $1,85 \pm 0,14$ & \\
Aeruginosa & $\mathrm{y}=-1 \times 10^{13} \mathrm{x}+8 \times 10^{13}$ & 0,73 & & \\
& $\mathrm{y}=-1 \times 10^{13} \mathrm{x}+7 \times 10^{13}$ & 0,63 & & \\
&
\end{tabular}


Teknologi Hasil Ternak, Universitas Tadulako, yang telah memberikan fasilitas sehingga penelitian ini dapat terlaksana.

\section{DAFTAR PUSTAKA}

Alhaddad, Z. A., Wahyudi, D., \& Tanod, W. A. (2019). Bioaktivitas antibakteri dari ekstrak daun mangrove Avicennia sp. Jurnal Kelautan: Indonesian Journal of Marine Science and Technology, 12(1), 12-22.

Badan Standarisasi Nasional [BSN]. (2006). Penentuan Angka Lempeng Total. SNI-01-2332.3-2006. Badan Standarisasi Nasional. Jakarta.

Bloomfield, S. F. (1991). Methods for assessing antimicrobial activity. In S. P. Denyer \& W. B. Hugo (Ed.). Mechanism of Action of Chemical Biocides Their Study and Exploitation (pp.256258). London: Blackwell Scientific Publication.

Blunt, J. W., Copp, B. R., Keyzers, R. A., Munro, M. H. G., \& Prinsep, M.R. (2013). Marine natural products. Natural Product Report, 30(2), 237323.

Chasanah, E. (2008). Marine biodiscovery research in Indonesia: challenges and rewards. Journal of Coastal Development, 12(1), 1-12.

Chen, W., Li, Y., \& Guo, Y. (2012). Terpenoids of Sinularia soft corals: chemistry and bioactivity. Acta Pharmaceutica Sinica B, 2(3), 227-237.

Cheng, S. Y., Huang, K. J., Wang, S. K., Wen, Z. H., Chen, P. W., \& Duh, C. Y. (2010). Antiviral and anti-inflammatory metabolites from the soft coral Sinularia capillosa. Journal of Natural Products, 73(4), 771-775.

Colin, P. L. \& Arneson, C. (1995). Tropical pacific invertebrates. A field guide to the marine invertebrates occurring on tropical pacific coral reefs, seagrass beds and mangrove. California: Coral reef Press.

Cowan, M. M. (1999). Plant products as antimicrobial agents. Clinical Microbiology Reviews, 12(4), 564-582.

Dewanto, D. K., Finarti, Hermawan, R., Ndobe, S., Haryadi, P. H., \& Tanod, W. A. (2019). Aktivitas antioksidan ekstrak karang lunak asal Teluk Palu, Sulawesi Tengah, Indonesia. Jurnal Pengolahan dan Bioteknologi Kelautan dan Perikanan, 14(2), 163-178.

Dobretsov, S., Al-Wahaibi, A. S. M., Lai, D., AlSabahi, J., Claereboudt, M., Proksch, P., \& Soussi, B. (2015). Inhibition of bacterial fouling by soft coral natural products. International Biodeterioration \& Biodegradation, 98, 53-58.

European Committee for Antimicrobial Susceptibility Testing [EUCAST]. (2003). Determination of minimum inhibitory concentrations (MICs) of antibacterial agents by broth dilution. Clinical Microbiology and Infection, 9(8), 9-15.

Fabricus, K., \& Alderslade, P. (2001). Soft Corals and sea fans, a comprehensive guide to the tropical shallow-water genera of the central-west Pasific, The Indian Ocean and the Red Sea. Queensland: Australian Institute of Marine Science.

Fattorusso, E., Romano, A., Taglialatela-Scafati, O., Janib Achmad, M., Bavestrello, G., \& Cerrano, C. (2008). Lobozoanthamine, a new zoanthaminetype alkaloid from the Indonesian soft coral Lobophytum sp. Tetrahedron Letters, 49(14), 2189-2192.

Fattorusso, E., Luciano, P., Putra, M. Y., TaglialatelaScafati, O., Ianaro, A., Panza, E., \& Cerrano, C. (2011). Chloroscabrolides, chlorinated norcembranoids from the Indonesian soft coral Sinularia sp. Tetrahedron, 67(41), 7983-7988.

Harborne, J. B. (1998). Phytochemical Methods; A Guide to Modern Techniques of Plant Analysis. (Vol. 3). London New York: Chapman and Hall.

Handayani, D., Edrada, R. A., Proksch, P., Wray, V., Witte, L., Van Ofwegen, L., \& Kunzmann, A. (1997). New oxygenated sesquiterpenes from the Indonesian soft coral Nephthea chabrolii. Journal of Natural Products, 60(7), 716-718.

Hermawan, A., Eliyani, H., \& Tyasningsih, W. (2007). Pengaruh Ekstrak Daun Sirih (Piper betle L.) terhadap Pertumbuhan Staphylococcus aureus dan Escherichia coli dengan Metode Difusi Disk. Tesis. Fakultas Kedokteran Hewan: Universitas Airlangga. 
Higa, T., Tanaka, J., Ohtani, I. I., Musman, M., Roy, M. C., \& Kuroda, I. (2001). Bioactive compounds from coral reef invertebrates. Pure and Applied Chemistry, 73(3), 589-593.

Ianora, A., Boersma, M., Casotti, R., Fontana, A., Harder, J., Hoffmann, F., Pavia, H., Potin, P., Poulet, S.A \& Toth, G. (2006). New trends in marine chemical ecology. Estuaries and Coasts, 29(4), 531-551.

Jia, R., Guo, Y., Mollo, E., \& Cimino, G. (2005). Natural product research: formerly natural product letters two new 19-oxygenated polyhydroxy steroids from the Hainan soft coral Sinularia sp. Natural Product Research, 19(December), 789-794.

Khatab, R. M. A., Ali, A. E., El-Nomary, B., \& Temraz, T.A. (2008). Screening for antibacterial and antifungal activities some selected marine organisms of the Suez Canal and Red Sea. Egyptian Journal of Experimental Biology (Zoology), 4(8), 223-228.

Kusmayati \& Agustini, N. W. (2007). Uji aktivitas senyawa antibakteri dari mikroalga (Porphyridium cruentum). Biodiversity, 8(1), 48-53.

Liang, L. F., \& Guo, Y. W. (2013). Terpenes from the soft corals of the genus Sarcophyton: chemistry and biological activities. Chemistry and Biodiversity, 10(12), 2161-2196.

Liang, L. F., Wang, X. J., Zhang, H. Y., Liu, H. L., Li, J., Lan, L. F., \& Guo, Y. W. (2013). Bioactive polyhydroxylated steroids from the Hainan soft coral Sinularia depressa Tixier-Durivault. Bioorganic \& Medicinal Chemistry Letters, 23(5), 1334-1337.

Lu, Y., Huang, C. Y., Lin, Y., Wen, Z., Kuo, Y., Chiang, M. Y., \& Su, J. H. (2008). Anti-inflammatory cembranoids from the soft corals Sinularia querciformis and Sinularia granosa. Journal of Natural Products, 71(10), 1754-1759.

Manuputty, A. E. W. (2002). Karang Lunak (Soft Coral) Perairan Indonesia (Buku I: Laut Jawa dan Selat Sunda). Jakarta: Pusat Penelitian Oseanografi-LIPI.
Minh, C. V., Kiem, P. V., Nhiem, N. X., Cuong, N. X., Thao, N. P., Nam, N. H., Anh, H. L. T., Tung, D. C., Thuy, D. T. T., Kang, H. K., Jang, H. D., \& Kim, Y. H. (2011). Cytotoxic and antioxidant activities of diterpenes and sterols from the Vietnamese soft coral Lobophytum compactum. Bioorganic and Medicinal Chemistry Letters, 21(7), 2155-2159.

Murniasih, T. (2005). Substansi kimia untuk pertahanan diri dari hewan laut tak bertulang belakang. Oseana, 30(2), 19-27.

Naidu, A. S. (2002). Natural Food Antimicrobial System. USA: CRC Press.

Putra, M. Y., Ianaro, A., Panza, E., Bavestrello, G., Cerrano, C., Fattorusso, E., \& TaglialatelaScafati, O. (2012). Sinularioside, a triacetylated glycolipid from the Indonesian soft coral Sinularia sp., is an inhibitor of NO release. Bioorganic \& Medicinal Chemistry Letters, 22(8), 2723-2725.

Putra, M. Y., Murniasih, T., Swasono, R. T., Wibowo, J. T., Saputri, A. N. C., Widhiana, M. R., \& Arlyza, I. S. (2016a). Secondary metabolites and their biological activities in Indonesian soft coral of the genus Lobophytum. Asian Pacific Journal of Tropical Biomedicine, 6(11), 909-913.

Putra, M. Y., Wibowo, J. T., Murniasih, T., \& Rasyid, A. (2016b). Evaluation of antibacterial activity from Indonesian marine soft coral Sinularia sp. American Institute of Physics Conference Proceedings, 1744, 020039-1-020039-5.

Putz, A \& Proksch, P. (2009). Chemical defence in marine ecosystems. In W. Michael (Ed.), Annual Plant Reviews, Volume 39: Functions and Biotechnology of Plant Secondary Metabolites (pp. 162-213). New Jersey: Blackwell Publishing Ltd.

Rachmaniar, R. (1995). Penelitian produk alam laut skreening substansi bioaktif. Laporan Penelitian Tahun Anggaran 1994/1995, Puslitbang Oseanologi. Jakarta: Lembaga Ilmu Pengetahuan Indonesia.

Radić, N., \& Strukelj, B. (2012). Endophytic fungi: the treasure chest of antibacterial substances. Phytomedicine: International Journal of 
Phytotherapy and Phytopharmacology, 19(14), 1270-1284.

Rajaram, S., Ramulu, U., Ramesh, D., Srikanth, D., Bhattacharya, P., Prabhakar, P., \& Navath, S. (2013). Anti-cancer evaluation of carboxamides of furano-sesquiterpene carboxylic acids from the soft coral Sinularia kavarattiensis. Bioorganic \& Medicinal Chemistry Letters, 23(23), 6234-6238.

Ravikumar, S., Gnanadesigan, M., Suganthi, P., \& Ramalakshmi, A. (2010). Antibacterial potential of chosen mangrove plants against isolated urinary tract infectious bacterial pathogens. International Journal of Medicine and Medical Sciences, 2(3), 94-99.

Riyadi, P. H., Wahyudi, D., \& Tanod, W. A. (2019). Effects of dichloromethane Sarcophyton spp. extract on the lipopolysaccharideinduced expression of nuclear factor-kappa $\mathrm{B}$ and inducible nitric oxide synthase inmice. Veterinary World, 12(12), 1897-1902.

Rozirwan, Bengen, D.G., Zamani, N.P., Effendi, H., \& Chaidir. (2014). Screening on the potential bioactive compounds of antibacterial activity in soft coral collected from South Bangka island waters and Lampung bay. Journal of Tropical Marine Science and Technology, 6(2), 283-295.

Salanggon, A., \& Finarti, F. (2016). Struktur populasi rekrut karang hermatifik pada metode fish home di Teluk Palu. Kauderni : Journal of Fisheries, Marine and Aquatic Science, 1(1), 33-38. Diakses 28 April 2020, dari https://jurnal.stplpalu.ac.id/ index.php/kauderni/article/view/10

Scheuer, J. S. (1994). Produk alami lautan : dari segi kimiawi dan biologi, jilid 1. Terj dari Marine Natural Products (Koensoemardiyah, Penerjemah). Semarang: IKIP Semarang Press.

Shaaban, M., Shaaban, K. A., \& Ghani, M. A. (2013). Hurgadacin: a new steroid from Sinularia polydactyla. Steroids, 78(9), 866-873.

Sheu, J. H., Ahmed, A. F., Shiue, R. T., Dai, C. F., \& Kuo, Y. H. (2002). Scabrolides A-D, four new norditerpenoids isolated from the soft coral Sinularia scabra. Journal of Natural Product, 65(12), 1904-1908.
Sun, P., Meng, L. Y., Tang, H., Liu, B. S., Li, L., Yi, Y., \& Zhang, W. (2012). Sinularosides A and B, bioactive 9,11-secosteroidal glycosides from the South China sea soft coral Sinularia humilis Ofwegen. Journal of Natural Products, 75, 1656-1659.

Tanod, W. A., Mangindaan, R. E. P., \& Kapojos, M. (2015). Antimitotic activity from soft coral genus Sinularia extracts. OmniAkuatika, 11(2), 41-49.

Tanod, W. A., Aristawati, A. T., Putra, M. Y., \& Muliadin. (2018). Soft coral (Sinularia sp.) extracts with antibacterial activity. OmniAkuatika, 14(1), 108-117.

Tanod, W. A., Yanuhar, U., Maftuch, Wahyudi, D., \& Risjani, Y. (2019a). DPPH scavenging property of bioactives from soft corals origin Palu bay, Central Sulawesi, Indonesia. IOP Conference Series: Earth and Environmental Science, 236(1), 012121.

Tanod, W. A., Dewanto, D. K., Ndobe, S., Riyadi, P. H., \& Putra, M. Y. (2019b). Screening of antibacterial and antioxidant activity from the soft corals Sinularia sp. and Sarcophyton sp. Origin Palu Bay, Central Sulawesi, Indonesia. Squalen Bulletin of Marine and Fisheries Postharvest and Biotechnology, 14(2), 73-83.

Tanod, W. A., Yanuhar, U., Maftuch, Putra, M. Y., \& Risjani, Y. (2019c). Screening of NO inhibitor release activity from soft coral extracts origin Palu bay, Central Sulawesi, Indonesia. AntiInflammatory \& Anti-Allergy Agents in Medicinal Chemistry, 18(2), 126-141.

Tseng, Y. J., Wang, S. K., \& Duh, C. Y. (2013). Secosteroids and norcembranoids from the soft coral Sinularia nanolobata. Marine Drugs, 11(9), 3288-3296.

Vickery, M. L., \& Vickery, B. (1981). Secondary Plant Methabolism. London: The Macmillan Press.

Wanda, E., Sadarun, B., \& Rahmadani. (2018). Keanekaragaman dan kepadatan karang lunak di perairan Waworaha kecamatan Soropia. Sapa Laut, 3(1), 9-15.

Wang, S. K., Hsieh, M. K., \& Duh, C. Y. (2012). Three 
new cembranoids from the Taiwanese soft coral Sarcophyton ehrenbergi. Marine Drugs, 10(7), 1433-1444.

Wiegand, I., Hilpert, K., Hancock, R. E. (2008). Agar and broth dilution methods to determine the minimal inhibitory concentration (MIC) of antimicrobial substances. Nature Protocols, 3(2), 163-175.

Yang, L., Wen, K. S., Ruan, X., Zhao, Y. X., Wei, F., \& Wang, Q. (2018). Response of plant secondary metabolites to environmental factors. Molecules, 23(762), 1-26. 
